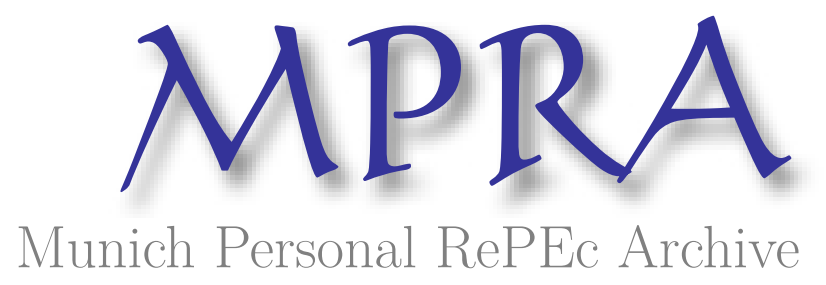

\title{
An Analysis of Migration Patterns and Local Government Policy toward Public Education in the United States
}

Cebula, Richard

Jacksonville University

5 June 1976

Online at https://mpra.ub.uni-muenchen.de/50913/

MPRA Paper No. 50913, posted 24 Oct 2013 16:29 UTC 


\section{Articles

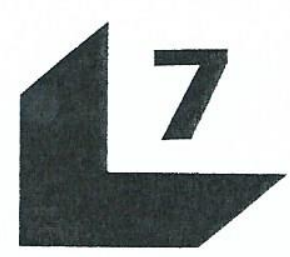

\section{AN ANALYSIS OF MIGRATION PATTERNS AND LOCAL GOVERNMENT POLICY TOWARD PUBLIC EDUCATION IN THE UNITED STATES}

\section{Richard J. Cebula*}

\section{INTRODUCTION}

In recent years, a number of studies have examined the relationship between migration and education [see, e.g., Folger and Nam (1967), Schwartz (1971) and (1976), and Shryock (1959)]. These studies have basically stressed the impact of the educational attainment of migrants on their mobility. However, little has been done formally to examine the effect per se of differential educational policies of local governments on geographic migration patterns. ${ }^{1}$

That local government policy toward, say, public education could potentially influence migration was, in a very real sense, suggested several years ago by Charles M. Tiebout (1956). Specifically, Tiebout (1956, p. 418) argued that

.. the consumer-voter may be viewed as picking that community which best satisfies his preference pattern for public goods...the consumer voter moves to that community whose local government best satisfies his set of

*Financial Aid from the Earhart Foundation is gratefully acknowledged.

${ }^{1}$ For an exception, see Pack (1973). Pack's analysis was a single-equation system estimated by ordinary least squares; moreover, a sample size of only 20 cities was used and her analysis was marred by numerous structural errors. See Cebula and Curran (1974). 
preferences.

More recently, in a somewhat different context, Gordon Tullock (1971, p. 917) has made a similar statement, namely, that "The individual deciding where to live will take into account the private effects upon him of the bundle of government services and taxes. .."

Accordingly, since public education is ordinarily the largest single budget item of local governmental units, it seems reasonable to conjecture that, if Tiebout and Tullock are correct in their hypotheses, differential local government commitments to public education may exercise a significant effect on household locational decisions, ceteris paribus.

By the same token, it would seem reasonable to argue that if public educational "quality" were important in the location decision, then the nature (quality) of public educational commitment should continue as well to be of concern, at least to some extent, after the move has been made. This continued concern in turn might then be reflected in household actions (the "vote," parent-teacher organizations, etc.) to further influence ("improve") the educational system in the household's new community of residence. Thus, not only is local government policy toward public education likely to be a possible influence on migration, but the public education policy itself may be influenced by migration. That is, with respect to local government policy toward (commitment to) public education on the one hand and migration patterns on the other, causality may run both ways.

Accordingly, the object of this paper is two-fold. First, it seeks empirically to ascertain the possible impact of differential local government policies toward (commitments to) public education on migration patterns. Second, it seeks to ascertain, simultaneously, the possible impact of migration patterns on local government policies toward public education. Section II analyses the problem by examining gross migration patterns to metropolitan areas over the 1965-1970 time period; Section III deals with net migration to metropolitan areas for the 1960-1970 period. Concluding remarks are found in Section IV of the paper.

\section{A MODEL OF GROSS MIGRATION TO METROPOLITAN AREAS}

To investigate the above two-pronged hypothesis empirically, we initially postulate the following model of gross in-migration to metropolitan areas:

$$
I i=I i(\dot{E} i, Y i, U i, C i, T i)
$$

where $\mathrm{Ii}=$ volume of gross non-elderly in-migration to area $\mathrm{i}, 1965-1970$, expressed as a percentage of the 1965 population in area $i$

$\dot{\mathrm{E}} \mathrm{i}=$ growth in public education spending per full-time student in area $i$, between 1965 and 1970, expressed in current dollars

$\mathrm{Yi}=$ per capita income in area $\mathrm{i}, 1965$

$\mathrm{Ui}=1965$ average unemployment rate in area $\mathrm{i}$ 
$\mathrm{C} i=$ number of days per year (on the average) when the temperature falls to $32^{\circ}$ Farenheit or below in area i

$\mathrm{Ti}=$ per capita property tax level in area $i, 1965$, expressed in current dollars.

Sufficient data for this study were available for assembly and computation for some 39 metropolitan areas. ${ }^{2} 3$

Areas which are committing themselves to more rapidly growing public education budgets (measured on a per full-time student basis) are presumably making stronger efforts to improve public education than areas not so rapidly expanding such budgets. Hence, to the extent that migrants are sensitive to local public goods (or, in this case, sensitive to the prospect of better public education), as Tullock (1971, p. 917) and Tiebout (1956, p. 418) argue, areas with more rapidly growing public education budgets (on a per full-time student basis) should be the more attractive ones to migrants, ceteris paribus. Thus, it is expected here that $\partial \mathrm{Ii} / \partial \dot{\mathrm{E} i}>0$.

Conventional migration theory argues that, ceteris paribus, migrants are attracted to areas offering higher income prospects. Hence, on the average, we would expect that $\partial \mathrm{Ii} / \partial \mathrm{Yi}>0$ [related to this, see, e.g., Gallaway (1969), Gallaway and Vedder (1971), and the comments by Sjaastad (1962)]. Similarly, except for migrants whose move is of a mere "job transfer" variety, the higher the unemployment rate in an area, the less attractive the area should be to migrants, ceteris paribus; hence we expect that $\partial \mathrm{Ii} / \partial \mathrm{Ui}<0$ [see e.g., Gallaway, et.al. (1967), Greenwood (1969), or Wadycki (1974)]. This is because higher unemployment rates imply greater risk about obtaining gainful employment. Migrants on the average presumably also prefer areas with warmer or more moderate climates to those with colder climates, ceteris paribus; hence, it is hypothesized that $\partial \mathrm{ri} / \partial \mathrm{Ci}<$ 0. This is consistent with several other studies [see, e.g., Graves (1976), Liu (1975), and Greenwood (1969)]. Finally, since higher property tax levels imply, ceteris paribus, that the cost of living is higher (at least in terms of paying for public sector goods, especially public education), it is argued that $\partial \mathrm{Ii} / \partial \mathrm{Ti}<0$. This variable was included in the analysis so as to permit migrants to appraise both benefits (public education) and costs (property taxation) associated with the local government

$2^{2}$ These data were gathered from various issues of the Statistical Abstract of the United States and the 1970 Census of the Population (1973a), (1973b). The initial efforts of Lori Dym during the Winter and Spring of 1976 are gratefully acknowledged.

${ }^{3}$ The metropolitan areas considered were Atlanta (Ga.), Austin (Tex.), Bakersfield (Cal.), Baltimore (Md.), Baton Rouge (La.), Boston (Mass.), Buffalo (N.Y.), Cedar Rapids (Iowa), Champaign-Urbana (Ill.), Chicago (Ill.), Cincinnati (Ohio, Ky., Ind.), Cleveland (Ohio), Dallas (Tex.), Dayton (Ohio), Denver (Colo.), Detroit (Mich.), Durham (N.C.), Green Bay (Wis.), Hartford (Conn.), Honolulu (Hawaii), Houston (Tex.), Indianapolis (Ind.), Kansas City (Mo., Kans.), Lancaster (Pa.), Los Angeles (Cal.), Milwaukee (Wis.), Minneapolis-St. Paul (Mn.), Nashville (Tenn.), New York (N.Y.), Orlando (Fla.), Philadelphia (Pa.-N.J.), Pittsburgh (Pa.), Portland (Maine), St. Louis (Mo., Ill.), San Diego (Cal.), San Franciso-Oakland (Cal.), Seattle-Everett (Wash.), Washington, D.C. (Md., Va.), and Witchita (Kans.). These were the only such areas having the needed cost of living (inflation) data mentioned below. 
sector [related to this joint consideration of government services and taxes see Tullock (1971, p. 917)].

The model for investigating the growth rate of educational spending in metropolitan areas (Éi) is initially given by

$$
\dot{E} i=\dot{E} i(I I, \dot{Y} i, \dot{F} i, \dot{L} i)
$$

where $\dot{\mathrm{E}} \mathrm{i}, \mathrm{Ii}=$ as above

$\dot{Y} \mathrm{i}=$ growth of per capital personal income in area i, 1965-1970, expressed in current dollars 4

$\dot{\mathrm{F}} \mathrm{i}=$ growth of federal education funding per full-time student in area $\mathrm{i}$, 1965-1970, expressed in current dollars 5

$\dot{\mathrm{L}}_{\mathrm{i}}=$ rate of inflation in area $\mathrm{i}, 1965-1970^{6}$

Regarding the relationship between $\dot{\mathrm{E}} \mathrm{i}$ and $\mathrm{Ii}$ in (2), it is argued (as suggested in the Introduction) that migrants concerned over the nature of the local government commitment to public education will, at least to some extent, continue their interest and concern beyond the mere decision as to where to move; the concern should continue into the new community of residence. In other words, once they have migrated, they will likely take some form of active role in pressuring their new community of residence to continue (increase) the effort to "upgrade" the local public education system. These migrants may form a political coalition (or join an already existing one) and pressure for more (and perhaps more efficient) educational spending through the vote. They also may choose to act (agitate) via parent-teacher associations or through other such mechanisms. In any event, it is argued that these migrants will add momentum to a drive to upgrade the local public school system; thus, we argue that $\partial \dot{\mathrm{E}} \mathrm{i} / \partial \mathrm{Ii}>0$.

Aside from this, in (2) it is argued that areas having higher growth in per capita income levels have faster growing bases from which to draw tax revenues. In other words, ceteris paribus, the higher an area's per capita income growth, the greater. its potential ability to finance growing public outlays for education; hence, it is hypothesized that $\partial \dot{E}_{i} / \partial \dot{Y}_{i}>0$. Similarly, the greater the growth of federal education funding (on the per full-time student basis) in an area, the faster its capacity to finance growing public education spending will increase, ceteris paribus. Hence, it is argued that $\partial \dot{\mathrm{E}} \mathrm{i} / \partial \dot{\mathrm{Fi}}>0$. Finally, $\dot{\mathrm{L}} \mathrm{i}$ is the inflation rate in area $\mathrm{i}$ for the period 1965-1970. It is argued here that, ceteris paribus, the greater the inflation

${ }^{4}$ The data on $Y i$ were computed from the Statistical Abstract of the United States, various issues.

${ }^{5}$ These data were obtained from the Digest of Educational Statistics, various issues. Thanks are again accorded to Lori Dym for data assembly.

${ }^{6}$ These data were obtained from the Statistical Abstract of the United States, (1968), (1973). 
rate in an area, the more rapidly education costs are likely to rise; hence, it is expected that $\partial \dot{\mathrm{E} i} / \partial \dot{\mathrm{Li}}>0$.

Simply estimating the linear forms of (1) and (2) using ordinary least squares (OLS), would not allow for any simultaneity that could exist between, say, Ii and Ei. In point of fact, the present paper argues that these two variables may very well be highly interdependent. Hence, in lieu of single-equation models estimated by OLS, what is needed is a multi-equation model estimated by, say, the two-stage, least-squares (TSLS) method.

Accordingly, the following two-equation system is to be estimated by TSLS:

$$
\begin{aligned}
& I i=a_{0}+a_{1} \dot{E} i+a_{2} Y i+a_{3} U i+a_{4} \mathrm{Ci}+a_{5} \mathrm{Ti}+a_{6} \\
& \dot{\mathrm{E} i}=b_{0}+b_{I} I i+b_{2} \dot{Y}_{i}+b_{3} \dot{\mathrm{F}} i+b_{4} \dot{L} i+b_{5}
\end{aligned}
$$

where $\mathrm{a}_{0}, \mathrm{~b}_{0}=$ constants

$a_{6}, b_{5}=$ error terms.

The results from estimating system (3)-(4) by TSLS are

$$
\begin{aligned}
-0.44637 \mathrm{Ci}- & 0.08915 \mathrm{Ti}, \\
(2.29) & (i .69)
\end{aligned}
$$

and

$$
D F=33, \quad F=20.65
$$

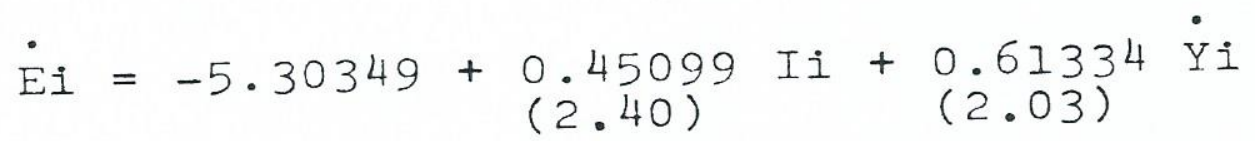

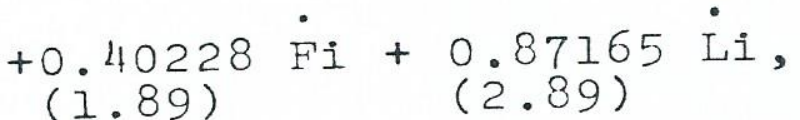

$$
\begin{aligned}
& D F=34, \quad F=27.66
\end{aligned}
$$

where terms in parentheses are $t$-values.

The results in (5) and (6) indicate that $\mathrm{Ii}$ and $\mathrm{Ei}$ are highly interdependent, i.e., that with respect to migration and the growth of local government spending on public education (per full-time student), causality appears to run both ways. This lends empirical support then to the two-pronged hypothesis offered at the outset of this paper.

As for specific results, in (5) observe that the income, climate, education, and property tax variables all had the expected signs and were statistically significant at 
the .05 level or beyond. Only the unemployment variable failed to be significant at an acceptable (.05) level. The results for education and the property tax clearly lend support for the above-cited arguments by Tullock (1971) and Tiebout (1956). In (6), all four explanatory variables had the hypothesized signs and were significant at or beyond the .03 level. Thus, local government policy toward public education was highly sensitive not only to migration, but also to per capita income growth, growth in federal education funding, and the rate of inflation.

\section{A MODEL OF NET MIGRATION TO METROPOLITAN AREAS}

In order to obtain further insight into the two-part hypothesis being examined in this paper, the following model of net in-migration to metropolitan areas was also considered:

$$
\begin{aligned}
& \mathrm{Mi}=\mathrm{Mi}\left(\dot{\mathrm{E}}_{i}, \mathrm{Y} i, \mathrm{U} i, \mathrm{C} i, \mathrm{~T} i\right) \\
& \dot{\mathrm{E}} i=\dot{\mathrm{E}}_{i}\left(\mathrm{Mi}, \dot{\mathrm{Y}}_{i}, \dot{\mathrm{F}} \dot{ }, \dot{\mathrm{L}}_{i}\right)
\end{aligned}
$$

where $\mathrm{Mi}=$ volume of non-elderly net in-migration to area i, 1960-1970, expressed

$$
\begin{array}{ll}
\dot{\mathrm{E}} \mathrm{i}= & \text { as a percentage of the } 1960 \text { population in area } \dot{\mathrm{i}}^{7} \\
\mathrm{Y} \mathrm{i}= & \text { as above, except } 1960-1970 \\
\mathrm{Ui}= & \text { as above, except } 1960 \\
\mathrm{Ci}= & \text { as above } \\
\dot{\mathrm{Y}} \mathrm{i}= & \text { as above, except } 1960-1970 \\
\dot{\mathrm{F}} \mathrm{i}= & \text { as above, except } 1960-1970 \\
\mathrm{Ti} & \text { as above, except } 1960 \\
\dot{\mathrm{L}} \mathrm{i} & =\text { as above, except } 1962-1970 .
\end{array}
$$

Sufficient data were available for assembly and computation for some 39 metropolitan areas (the same 39 as in Section II).

On the basis of the arguments in Section II above, it follows that, for the partial derivatives in (7) and (8), we should expect

$$
\begin{aligned}
& \frac{\partial M i}{\partial \dot{E} i}, \frac{\partial M i}{\partial Y i}>0 \\
& \frac{\partial M i}{\partial C i}, \frac{\partial M i}{\partial U i}, \frac{\partial M i}{\partial T i}<0
\end{aligned}
$$

${ }^{7}$ For Mi, see the Statistical Abstract of the United States: 1973 (1973), Section 33 and the 1970 Census of the Population (1973 b). 
and

$\frac{\partial \dot{E} i}{\partial \dot{L} i}, \frac{\partial \dot{E} i}{\partial M i}, \frac{\partial \dot{E} i}{\partial \dot{Y} i}, \frac{\partial \dot{E} i}{\partial \dot{F} i}>0$

Estimating (in the linear form) the two-equation system (7)-(8) by TSLS yields the following results:

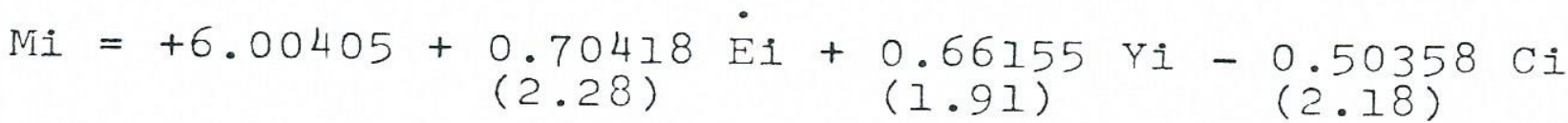

$$
\begin{aligned}
& \begin{array}{l}
-0.10314 \mathrm{Ui}-0.09405 \mathrm{Ti}, \\
(0.96)
\end{array} \\
& D F=33 \quad F=21 \cdot 34 \\
& \dot{E i}=-5.76344+\underset{(2.39)}{(2.40366 \mathrm{Mi}+} \begin{array}{c}
0.60519 \\
(2.01)
\end{array} \\
& +\underset{(1.90)}{+0.46124 \dot{F}+}+0.85324 \dot{\mathrm{L} i}, \\
& D F=34, \quad F=28.98
\end{aligned}
$$

where terms in parentheses are t-values.

Overall, these results are entirely compatible with those for gross migration in the estimated system (5)-(6). Once again, empirically speaking, the causality between migration and local government policies toward public education seem to run both ways. The present results thus provide additional support for the two-pronged hypothesis offered in the Introduction.

In addition, net in-migration was significantly affected not only by the education variable but also by considerations of income, property taxation, and climate. Thus, we once again observe support for the above-cited arguments by Tullock (1971) and Tiebout (1956). Finally, not only was local government policy toward public education very responsive to net in-migration, but it was also highly responsive to per capita income growth, growth in federal education funding, and the rate of inflation.

\section{CONCLUDING REMARKS}

This paper has argued that migration patterns and local government policy toward public education are highly interdependent, i.e., that the causality runs both ways. Empirical support for this argument has been found in a study of both gross migration (Section II) and net migration (Section III) to metropolitan areas in the United States.

These results, at least in part, thus offer support to the above-cited 
arguments $^{8}$ by Tullock (1971, p. 917) and Tiebout (1956, p. 418) that, ceteris paribus, consumer-voters move to communities whose local governments best satisfy their public goods preferences. Moreover, it also seems that, in the case of public education, there is actually a dynamic process wherein the consumer-voter acts further to influence local government policies in his new community of residence. In turn, this over time may to some extent lead to policies which accentuate the differences between areas in their provision of public education. Consequently, it seems entirely possible that this may create further problems of a private-versus-social costs and benefits nature for the United States. ${ }^{9}$ However, that is a subject beyond the scope of this paper.

\section{REFERENCES}

R. J. Cebula and C. Curran. "Determinants of Migration to Central Cities: A Comment." Journal of Regional Science, (August, 1974), 289-293.

G. F. DeJong and W. L. Donnelly. "Public Welfare and Migration." Social Science Quarterly, (September 1973), 329-344.

John K. Folger and Charles B. Nam. "Education of the American Population." 1960 Census Monograph, U.S. Bureau of the Census, Washington, D.C.: 1967.

L. E. Gallaway. "Age and Labor Mobility Patterns." Southern Economic Journal, (October, 1969), 171-180.

L. E. Gallaway, R. F. Gilbert, and P. E. Smith. "The Economics of Labor Mobility: An Empirical Analysis." Western Economic Journal, (June, 1967), 211-223.

L. E. Gallaway and R. K. Vedder. "Mobility of Native Americans." Journal of Economic History, (September, 1971), 613-649.

P. Graves. "A Note on Migration, Economic Opportunity, and the Quality of Life Comment." Journal of Regional Science, (April, 1976), 107-112.

M. J. Greenwood. "An Analysis of the Determinants of Geographic Labor Mobility in the United States." Review of Economics and Statistics, (May, 1969), 189-194.

J. B. Kau and C. F. Sirmans. "New, Repeat, and Return Migration: A Study of Migrant Types." Southern Economic Journal, (October, 1976), 1144-1148.

B. C. Liu. "Differential Net Migration Rates and the Quality of Life." Review of Economics and Statistics, (August, 1975), 329-337.

J. R. Pack. "Determinants of Migration to Central Cities."Journal of Regional

${ }^{8}$ Support for the above-cited arguments by Tullock (1971, p. 917) and Tiebout (1956, p. 418) has, in terms of welfare benefits, been obtained by a number of other studies, including DeJong and Donnelly (1973), Kau and Sirmans (1976), Sommers and Suits (1973), and Ziegler (1976).

${ }^{9}$ Related to various aspects of the issue of private-versus-social costs and benefits, associated with migration or residential choice see, e.g., Tullock (1971, esp. pp. 917-918), Riew (1973), and Sjaastad (1962). 
Science, (August, 1973), 249-260.

J. Riew. "Migration and Public Policy." Journal of Regional Science, (April, 1973), 65-76.

Aba Schwartz. "On Efficiency of Migration." Journal of Human Resources, (Spring, 1971), 193-205.

Aba Schwartz. "Migration, Age, and Education." Journal of Political Economy, Part 1, (August, 1976), 701-719.

H. S. Shryock. "The Efficiency of Internal Migration in the United States." Proceedings, International Population Conference, sponsored by the International Union for the Scientific Study of Population, Vienna, Austria: 1959.

L. A. Sjaastad. "The Costs and Returns of Human Migration." Journal of Political Economy, (October, 1973), Supplement, 80-93.

P. M. Sommers and D. B. Suits. "Analysis of Net Interstate Migration." Southern Economic Journal, (October, 1973), 193-201.

C. M. Tiebout. "A Pure Theory of Local Expenditures." Journal of Political Economy, (October, 1956), 416-424.

G. Tullock. "Public Decisions as Public Goods." Journal of Political Economy, (July/August, 1971), 913-918.

G. Tullock. Toward a Mathematics of Politics. Ann Arbor, Michigan: University of Michigan Press, 1967.

U.S. Bureau of the Census. Census of the Population: 1970, series PC(1)-C, General Social and Economic Characteristics, Washington, D.C., 1973, a.

U.S. Bureau of the Census. Census of the Population: 1970, Subject Reports, Final Report PC(2)-2C Mobility for Metropolitan Areas, Washington, D.C., 1973, b.

U.S. Bureau of the Census. Statistical Abstract of the United States, Washington, D.C., various issues.

U.S. Office of Education. Digest of Educational Statistics, Washington, D.C., various issues.

W. J. Wadycki. "Alternative Opportunities and Interstate Migration: Some Additional Results.' Review of Economics and Statistics, (May, 1974), 254-257.

J. Z. Ziegler. "Black Interestate Migration: Comment and Further Evidence." Economic Inquiry, (September, 1976), 449-453. 